\title{
First report of celery mosaic virus in Turkey
}

\author{
Ali Karanfil ${ }^{1}$ - Savas Korkmaz ${ }^{1}$ Bayram Cevik ${ }^{2}$ \\ Received: 20 March 2019 / Accepted: 5 April 2019/Published online: 23 April 2019 \\ (C) Società Italiana di Patologia Vegetale (S.I.Pa.V.) 2019
}

Keywords Potyvirus $\cdot \mathrm{CeMV} \cdot$ Detection

Celery mosaic virus (CeMV), which causes mosaic, veinclearing, and dwarfing symptoms in celery (Apium graveolens), is a member of the genus Potyvirus in the family Potyviridae (Rose and Maiss 2018). In 2018-2019, symptoms reminiscent of CeMV were seen in celery plants in commercial celery production areas in the Çanakkale province, Turkey. Twenty-one symptomatic celery samples were collected for total nucleic acid extraction by the CTAB method (Li et al. 2008). Two-step RT-PCR was performed using a degenerate potyvirus-specific primer pair (Zheng et al. 2010). As a result, 19 out of 21 collected samples revealed a DNA band of about $350 \mathrm{bp}$ in size, as expected. One of the RT-PCR products, designed as TRCNK, was randomly chosen, cloned into pGEM®-T easy vector system II (Promega, USA), and sequenced. The CeMV sequence was deposited in GenBank with the accession number MK575467. A BlastN analysis of the sequence against the GenBank database resulted in more than $96 \%$ identity with other CeMV isolates. To confirm the presence of CeMV, a new primer pair (CeMV_CPF_5'-GAGATGGCGGAGGAAGAA-3' and CeMV_CPR_5'-ACTGCATAAACCGAAAGGA-3') was designed to amplify the complete CeMV coat protein gene

\section{Ali Karanfil}

ali.karanfil@hotmail.com

Savas Korkmaz

skorkmaz@comu.edu.tr

Bayram Cevik

bayramcevik@sdu.edu.tr

1 Department of Plant Protection, Faculty of Agriculture, Canakkale Onsekiz Mart University, Canakkale, Turkey

2 Department of Plant Protection, Faculty of Agricultural Sciences and Technologies, Applied Sciences University of Isparta, Isparta, Turkey by RT-PCR. An amplicon (980 bp) of the expected size was obtained from the same 19 samples that tested positive in RTPCR with the universal potyvirus primer pair. A randomly chosen RT-PCR product was purified and directly sequenced. The sequence of the complete CP gene ( $834 \mathrm{bp}$ ) was deposited in GenBank with the accession number MK570304. BlastN analysis of the sequence indicated 96-98\% identity with other CeMV isolates for which sequence information is available in GenBank. To the best of our knowledge, this is the first report of CeMV in Turkey.

Acknowledgements We would like to thank to Dr. Igor Koloniuk for constructive comments on this manuscript.

\section{Compliance with ethical standards}

Conflict of interest All authors declare that they have no conflict of interest.

Ethical approval This article does not contain any studies with human participants or animals performed by any of the authors.

\section{References}

Li R, Mock R, Huang Q, Abad J, Hartung J, Kinard G (2008) A reliable and inexpensive method of nucleic acid extraction for the PCRbased detection of diverse plant pathogens. J Virol Methods 154: 48-55. https://doi.org/10.1016/j.jviromet.2008.09.008

Rose H, Maiss E (2018) Complete genome sequence and construction of an infectious full-length cDNA clone of a German isolate of celery mosaic virus. Arch Virol 163:1107-1111. https://doi.org/10.1007/ s00705-018-3705-1

Zheng L, Rodoni BC, Gibbs MJ, Gibbs AJ (2010) A novel pair of universal primers for the detection of potyviruses. Plant Pathol 59:211220. https://doi.org/10.1111/j.1365-3059.2009.02201.x

Publisher's note Springer Nature remains neutral with regard to jurisdictional claims in published maps and institutional affiliations. 